\title{
Akan Pre-eventive Apologies or Apologetic Signals
}

\author{
Yaw Sekyi-Baidoo
}

\begin{abstract}
Apologies have been seen generally as post-eventive acts which seek to repair damage to rapport. A study of the nature of apologies among the Akan reveals, however, that there exists also a strong tradition of pre-eventive apologies, by which one apologises for an impending damage to rapport or threat to another's face.

This paper investigates pre-eventive apologies among the Akans of Ghana. It looks at the basic differences between the pre- and the post eventive apologies and attempts to place each of them within the general framework of politeness. Again, the paper studies the felicity conditions or the sociopragmatic as well as the pramalingual principles that govern the effective use of pre-eventive apologies. The paper establishes that though the Akan places a lot of importance on post-eventive apologies as a politeness strategy, pre-eventive apologies are also deemed to be very crucial in determining one's politeness as well as one's communicative competence; since they unlike the post-eventive, prevent or avoid rather than repair damages to rapport and politeness.
\end{abstract}

Finally the paper discusses situations in which the principles of pre-eventive apologies may be exploited for impoliteness.

Index Terms-Apology, face, politeness, pre-eventive.

\section{APOLOGY AND Politeness}

Whereas Brown and Levinson [1] and Leech [2] seem to stress a so-to-speak more individualistic view to face and politeness, Matsumoto and Ide from an eastern perspective see face and politeness as a social resource which is accessed in the complementary roles of encoding and decoding of speech. It is, however, evident that these two perspectives to politeness are never exclusive. Indeed, in no social or linguistic community is face or politeness an exclusively individual or communal venture. Politeness and face may still be communal constructs, but they manifests not in general, static or universal terms, but in respect of the exigencies of speech - of person and context. The social dimensions of politeness is evident also in the idea that communicative competence and solidarity are social concepts, which become evident partly in one's ability to conform to socially acceptable or appropriate norms of interaction, paramount of which is the idea of politeness. It is in the light of the above that one can consider Ide's idea of discernment and volition in politeness [3], which succinctly captures the social background of the use of apologetic strategies among the Akans also:

The practice of polite behaviour according to social conventions is known as wikimae in Japanese. To behave

Manuscript received September 29, 2015; revised July 11, 2016.

Yaw Sekyi-Baidoo is with the Division of International Relations and Public Affairs of the University of Education, Winneba, Ghana (e-mail: ysekyibaidoo@gmail.com). according to wikimae is to show verbally and non-verbally one's sense of place or role in a given situation according to the social conventions... The choice of linguistic forms or expressions in which the distinction between the ranks or roles of speaker, the referent and addressee are systematically encoded will be called the discernment aspect of linguistic politeness....

In contrast to the discernment aspect, the politeness which allows the speaker a considerable active choice according to the speaker's intention from a relatively wider set of possibilities is called the 'volitional aspect'.

This social aspect of politeness is taken up further in Mastsumoto [4] who asserts:

. . .no utterance in Japanese can be neutral with respect to the social context... a Japanese speaker cannot avoid conveying the setting and the relationship among the addressee, the third person(s), and object(s) in the utterance and him/herself.

Apologies and apologetic signalling can be seen to belong to the two preoccupations of politeness both as a conflict-avoidance strategy and as a socially-indexing resource. As a conflict-avoidance strategy, apology (and as an aspect of politeness) control potential aggression, avoid disruption of interaction and maintains social equilibrium thereby ensuring smooth communication. Apologies may also be seen as in terms of the Rapport Enhancement and Rapport Maintenance orientations of Spencer-Oatey's Rapport Management. Spencer-Oatey [5] defines rapport management to 'include any kind of behaviour that has an impact on rapport, whether negative, positive or neutral'; and the various orientations of rapport management are explained as follows:

... a rapport-enhancement orientation (the desire to strengthen or enhance harmonious relations), a rapport-maintenance orientation (a desire to maintain or protect harmonious relations among interlocutors), a rapport-neglect orientation (a lack of concern or interest in quality of relations, perhaps because of focus on self) or a rapport-challenge orientation (a desire to challenge or impair harmonious relation.)

This view of apology is similar to Holmes [6] below, whose use of the idea of restoring social relations can be seen to be equivalent to the rapport maintenance strategies of Spencer-Oatey (ibid):

An apology is a polite speech act used to restore social relations following an offence. Apologies therefore redress face-threatening behaviour, and they acknowledge the need of the addressee not to be imposed upon or offended. 
Our discussions of apologetic signals ties in also with the frame-based approach to the analysis of politeness which recognises the complementary consideration of both Self and Other (speaker and hearer) whose face needs are mutually negotiated and catered for in any interaction as discussed by Terkorafi, an idea which recalls Goffman [7]. As we shall see in our discussions, apologetic signals are not just individual decisions or choices; rather they are based on established patterns of sociolinguistic behaviour ${ }^{1}$ which are understood by both addressor and addressee:

...the speaker's individual rationality is constrained on this occasion by a societal rationality... The requirement to be recognisable applies not only to individual intentions, but also to ways of face threatening/enhancing which are also socially constituted [8].

This role of the society both in the constitution and interpretation of speech acts is more crucial with apologetic signals than in normal post-event apologies, since unlike the post-event apologies, pre-eventive apologies are normally not negotiated. Post-event apologies include, as part of the total act, the need for the addressee to accept the apology. Pre-eventive apologies (or pre-acts) do not usually have a place for addressee acceptance, since they are organised as part of sentences or as part of a running turn. In this way, pre-act apologies may be seen as more direct indexes to politeness and general communicative competence.

Though Agyekum [9], Wardaugh [10] and Blum-Kulka and Olshtain [11] acknowledge that apologies may be progressive i.e. of actions or utterances yet to be made, they generally see apology as a retrogressive speech act. Agyekum (ibid), however, draws some attention to the pre-event use of apologies in his discussion of apologies in Akan Ntam (major reminiscential oaths) as a way to 'tactfully minimise the offensive power of the taboo'. By the expressions 'prefaced' and 'impending', Agyekum acknowledges the use of pre-eventive apologies among Akans:

The apology implies that s/he should not be misconstrued as being rude and uncaring and verbally assaulting the audience by reminding them of the past predicament. S/he thus prefaces his/her utterance with the apologetic tag sre to express warm and positive concern... the use of mesre 'I beg or apologise' serves to mitigate and soften the force of the impending FTA (bold mine).

The purpose of this paper is to investigate the use of the expressive speech act of pre-eventive apologies or apologetic signals among the Akans. It establishes that the difference between the pre-eventive and the post-eventive forms which have been the focus of most of the discussions on apology is not only in the fact that one comes before the offence, whilst

\footnotetext{
${ }^{1}$ For other relevant studies by Terkorafi, Mariama Terkorafi, 'Testing Brown and Levinson's theory in a corpus of conversational data from Cypriot Greek. International Journal of the Sociology of Language 168, 2004, 119-134; and 'Generalized and particularized implicatures of politeness', in Perspectives on Dialogue in the New Millennium. Peter Kühnlein, Hannes Rieser, and Henk Zeevat (eds.), Amsterdam: John Benjamins, 151-166.
}

the other comes after it; but also, and most importantly, they are governed by different sociopragmatic and pramalingual rules.

\section{Felicity Conditions of PRE-EVEntive Apologies}

Pre-eventive apologies, like all speech acts, require certain conditions for its effective realization. Wagner [12], for instance, states these conditions to include:

1) A specific definition of the perceived offense,

2) Acknowledging that the perceived offense caused harm,

3) Taking responsibility,

4) Recognition of wrongdoing,

5) A statement of regret,

6) A promise not to repeat the offense,

7) An explanation of why the offender acted this way.

Certainly, the conditions described above, for their backtracking orientation, cannot account for pre-eventive apologies which are essentially progressive rather than retrogressive. Conditions 1 - 5 somehow apply also to pre-eventive apologies, but all these are seen and catered for even before the offence, and are encapsulated in the meaning of the formulaic apologetic signal. The following may be seen as the felicity conditions of pre-eventive apologies (apologetic signals):

1) That the issue for which apology is being sounded has a face threatening effect.

2) That in spite of the face threat potential, there is still an irresistible need for that speech.

3) The IFID which is the formulaic expression must be commensurate with the level of face threat.

Our discussions of the felicity conditions here will concentrate mainly on the second of the three which sum up in exigency and inevitability. This is not to play down the importance of the other two. The place of these others will become evident in the analysis of the various groups of contexts which call for the use of pre-eventive apologies as well as in the discussions of the pragmatic functions of pre-eventive apologies.

\section{A. Felicity Condition 1 - Existence of Face-Threat}

The use of taboo expressions, reminding one of events of displeasure aspects, reference to attributes which highlight the speaker or another to hearer' disadvantage, interruptions and digressions in speech, and exhibition of divisive tendencies may be seen as constituting a cross-section of the various face-threat groups to which Akans respond with pre-eventive apologies.

\section{B. Felicity Condition 3 - Use of Commensurate or Appropriate Apologetic Signal}

With respect to the felicity condition on the use of appropriate linguistic form or apologetic signals, it will be recognised, as has been intimated above, that the linguistic forms selected for the various forms of face-threat are not arbitrary, but are based on the nature of the face threat itself and the exigency associated with the face-threat. The use and relevance of the linguistic forms will be evident in the discussions of the face-threats as well as the impolite use of pre-eventive apologies. 


\section{Felicity Condition 2 - Exigency and Inevitability}

In Pre-eventive apologies, unlike in post-eventive ones, one knows and acknowledges the impoliteness of one's speech before making it. If this impoliteness still occurs, then one would ask:

Why would one use an expression one knows to be face-threatening expression instead of avoiding it?

The pre-apologized act is considered as a necessary and unavoidable face threat; and this is associated with the substance or ontology, or the delivery or presentation of the face-threatening act. The following sociopragmatic principle, thus, guides the use of pre-eventive apologies

Pre-eventive apologies are used when the item mentioned is normally deemed face-threatening. Therefore use pre-eventive apologies only when such a face-threatening thing, fact, thought or expression is necessary and inescapable.

The ontology of substance of the act refers to the nature of the action, state, being, fact, thing, or person that is being referred to. In Akan culture, some things are said to be inherently face threatening or impolite, or that they undermine the solidarity and rapport of society. On the other hand, some acts are face threatening, not because the propositions in them are so naturally, but because the most polite or the least face threatening way has not been used.

Owing to the face-threat associated with the experiences or circumstances of pre-eventive apologies, it is expected that one would use them only when it is very necessary or unavoidable, compelling the speaker to mention the face-threatening substance or experience, or use an expression other than the most polite. For instance, reference to another's childlessness or that one is the offspring of a slave will be made only when it can be adjudged from the context that such a reference is crucial to the ends of the discourse. Again, a euphemism of a more polite form of an experience may be avoided and the face-threatening one used, if it is established that the choice of this euphemistic form may bring ambiguity or impair the frankness that is demanded by the context. There are cases in point, for instance, when it has been insisted by adjudicators in a dispute that the more face-threatening form of an idea is used in order to achieve precision and avoid lack of clarity or ambiguity. The following exchange may be illustrative:

Speaker:

- Akyire yi na mehunuu ss, bere a mehyiaa me yere da edi kan no na wafa afuru dada.

-(After this and I saw that time the I met my wife day which-comes first-the then she has taken a belly already).

-( 'Later I discovered that when I met my wife for the first time, she was already pregnant.')

Adjudicator 1:

Wohyiaa no wə \&henfa? Abonten so hə?

(You-met her at which-part? Street on there?)

(Where did you meet her? Out in the street?)

- Dabi, Nana, Se əbarima ne sbaa hyia.

(No, Grandsire, as man and woman meet.)

('No, Nana, as a man and a woman meet.')

Adjudicator 2

- Eno dee na yi anim na ka no yie.

- (That else then clear the face and say it well.)

- ('Then say it clearly and precisely.')

\section{Speaker}

- Nana, moanim o, mehunuu se sebe mene me yere dii Mpaso agor a edi kan no see na w'afa afuru dada.

-(Grandsire, in your presence, I saw that, apologies, I and my wife celebrated Bed-top game which places first she had gotten a belly already.)

,- ('Nana, apologies that this is in your presence, I

discovered later that when I, apologies, engaged in the first

bed-game with my wife, she was already pregnant.')

According to Adjudicator 1, the expression 'hyia me yere' brings ambiguity. This is because the expression which is a euphemism for 'mating my wife' may also be interpreted to mean literally the physical activity of 'a man meeting his wife'. This second meaning is what is called up in the question of place or location, 'Abonten so hə?' (in the street?). The adjudicator explored the polysemy of the verb hyia (to meet). To the adjudicator, there is a great need to avoid the euphemistic term, and use the rather face-threatening but precise expression.

Each of the two principles of conciseness and precision on the one hand, and face threat on the other, can be put on a cline, and the choice of which expression in any discourse depends on which of them is more crucial according to the end of the discourse, the participants and the scene or setting as well as other factors of ethnography. The following are the politeness and precision grids for the face-threatening idea to have sex with a woman and barrenness:

\begin{tabular}{lcc}
\multicolumn{3}{c}{ To have sex with a woman } \\
Precision & Politeness \\
Medii no & 6 & $\begin{array}{c}\text { Mehunuu no } \\
\text { I ate her } \\
\text { 'I fucked her' }\end{array}$
\end{tabular}

'I fucked her'

Mene no dae

I with her slept

5 Me ne no hyiaae.

5

'I slept with her'

I with her met.

'I met her'

Mene no dii mpa so agoro. 4. Mefaa no.

I with her ate bed on game.

'I engaged her in bed games'

\section{Me ne no hyiaae \\ I with her met. \\ 'I met her'}

Mefaa no

I took her.

'I took her'.

Mehunuu no
1
I saw her.
'I saw her.

I took her.

'I took her'

3 Mene no dae.

I with her slept

'slept with her.

2 Mene no dii mpa so agoro 2 I and her played bed-on game. (I engaged her in bed games)

1 Medii no.

I ate her

'I fucked her 


\section{Childlessness}

\section{Precision}

Politeness

\begin{tabular}{|c|c|}
\hline 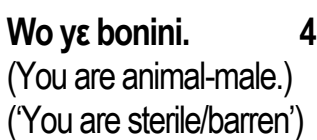 & $\begin{array}{l}\text { Nyame endoom wo ba } 4 \\
\text { (God not PERF-give you child.) } \\
\text { ('God hasn't given you the gift of a child'.) }\end{array}$ \\
\hline
\end{tabular}

Wonni ba

3 Wonwoor. 3

(You not have child.) (You not PERF give birth.)

('You don't have a child/ 'You haven't given birth'.)

You are childless'.)

$\begin{array}{lll}\text { Wonwoor. } & 2 & \text { Wonni ba. } \quad 2 \\ \text { (You not have given birth) } & \text { (You not have child.) } \\ \text { You haven't given birth' } & \text { ('You don't have a child/ } \\ & \text { You are childless.') }\end{array}$

Nyame हndoom wo ba. 1 Wo ye bonini. 1

(God hasn't given you child.) (You are animal-male.)

('God hasn't given you ('You are infertile.')

the gift of children.)

It may be necessary to explain the varying face-threatening properties of the expressions for childlessness. This might explain why 'Nyame endoom wo ba' is considered the least face-threatening, and also why any of 'Wonwoos' and 'Wonni ba' may be accepted in pre-eventive apologies.

The choice is generally for the expression which shows a balance between clarity and precision, on the one hand, and mitigated face-threat or politeness on the other. In this regard, it is unacceptable for one to use what is considered the most face-threatening expression or a highly face-threatening expression when there is another available expression which has a mitigated face-threat, and which still has the same or high level of clarity in sense. For instance, the expression 'medii no' (I had sex with her) is not considered polite in spite of the fact that one may precede it with 'the apologetic form 'sebe' or 'moanim a'. Similarly, the apology in the use of scbe is rendered useless or neutralised if it is used with the very face-threatening expression 'Wonwooe' or 'Wonni ba' or 'Wo y $\varepsilon$ bonini' in worsening impoliteness, when one could say 'Nyame endoom wo ba' which is still as precise in sense.

It may be necessary to explain the varying face-threatening properties of the expressions for childlessness. This might explain why 'Nyame endoom wo ba' is considered the least face-threatening, and also why any of 'Wonwooe' and 'Wonni ba' may be accepted in pre-eventive apologies. 'Wonwooe' may be said to be less face-threatening than 'Wonni ba' because it focuses on the activity of childbirth rather than having children, which is the result of the activity of childbirth. By so doing, 'Wonwooe' is able to deemphasise the loss which 'Wonni ba' highlights. But none of them rules out the possibility of one getting a child in future. For this reason, these expressions may be considered polite enough for adults who have as yet not passed their normal procreative years. It is in this sense that they are considered less impolite than 'Wo ye bonini' which precludes any hope of one getting a child. Again, it is generally less offensive to describe people using their conditions than their natural or inherited state or being. "Nyame Endoom wo Jba' removes the responsibility and possible blame of childlessness from humans to providence. In addition to the sympathy or solidarity in this expression, it also gives the indication that it is there is the possibility of one giving birth. Thus, there are two levels of politeness in the use of pre-eventive apologies:

- Choice of appropriate polite expression for activity, state or being

- Use of appropriate pre-eventive apology forms and it is these that are captured in the sociolinguistic principle above which explains also that the politeness in the use of pre-eventive apology forms is useless or ineffectual unless such due politeness has already been exercised in the selection of the expression to which the apology is attached. The following expressions gyimi (be foolish), ohiani (poor - especially. for first or third persons), bonini (barren/childless/sterile), dכnkつni (slave) bini (faeces/excreta) etc are, for instance, naturally high-ranged FTAs. To precede them with apologetic forms is therefore inappropriate, and does not succeed in averting the face threat.

\section{DOMAINS OF FACE-THREAT}

At this juncture, we will, in respect of the felicity condition of the existence of face threat, discuss various situations which are considered to be face-threatening, and to which one would normally, except in very casual interaction, precede with apologetic signals. It should be understood that as intimated above, the factors of ethnography or contextual factors such as the participant and participant roles, scene, and key are very crucial in determining the perceived level of face-threat and even the need or exigency associated with concept or linguistic behaviour to which the apology is attached.

\section{Taboo Expressions - \\ Sexual Parts and Activities, Pubic Parts, Invectives}

Taboo expression in Akan, as seen here, can be seen as the use of expressions which directly (or even indirectly sometimes) refer to sexual or pubic parts, or scatological material. It includes also any expression which directly imputes negativity to any person or object referred to in speech. In the Akan culture such expressions are generally outlawed, and this is seen as part of the society's idea of politeness as 'socially appropriate behaviour"' face-threatening nature of these expressions is simply in the fact that they evoke images or emotions which are not normally pleasant to the addressee (and also the speaker himself). Based on the social orientation of face then, the use of these expressions threaten the face of both speaker and addressee - the speaker, for his having to use an expression which is face threatening, thereby 'besmearing' $\mathrm{him} /$ herself with the negativity associated with the terms in the culture; and the addressee, for being inflicted with the negative images associated with the terms.

By employing the apologetic signal, the speaker prepares the addressee for the unpleasantness of the 
expression, thereby reducing the shock of the negativity of the expression. By the apology also, the speaker indicates to the addressee that (s)he has no intention of threatening the face of the addressee by exposing him/her to socially inappropriate behaviour, thereby insulating the addressee (and any third person) from the impoliteness thereof.

The following signals are used in this face-threat:

- Sebe - apologies

- W'anim - (Lit.. Before you/In your presence)

- Mingyina Wo/mo anim (Not standing before you/Not standing in your presence.

Of these, $s \varepsilon b e$ is considered most common, and least polite or least apologetic. This, perhaps, is as a result of the frequent use of $S \varepsilon b e$ as an apologetic signal, thereby reducing its potency. Mingyina Wo/mo anim and its shorter form, W'anim/Moanim (In your presence) is considered more formal, and are therefore more acceptable in situations of higher social distance, as indexed in the level of the interactants or in the larger context of speech interaction.

Associated with the greater politeness of W'anim and Mingyina Wo/mo anim is the use of honorific address forms, usually Nana (grandsire), Nananom (grandsires), Papa/Egya (Father), Egyanom (Fathers), Mpaninfo (Elderly/Wise Ones), Enanom (Mothers). It is considered inappropriate to use these apologetic expressions without address forms which show the situational distance between the speaker and the addressee, since such honorific forms show positive politeness. They also tie in with Leech's maxim of 'maximising praise of Other'. The politeness could be further enhanced by prefixing the address form with the first person pronoun me (my), yen (our) in line with Scollon and Scollon's strategy of 'involvement' [13].

\section{REMINDing PEOPle of Events of DisPleasure - DEATHS, OATHS, MISFORTUNES}

Included in Leech's politeness maxims is the idea of sympathy, by which a speaker identifies him/herself with the pains and frustrations of the addressee. To fail to show such sympathy can be seen as threatening the face of the addressee. As intimated by Agyekum [14], one is considered 'as being rude and uncaring and [as] verbally assaulting the audience by reminding them of the past predicament. Reference to such events of displeasure is considered an act of hostility intended to reduce friendliness. Show of sympathy is considered an important act of solidarity. Thus, to make reference to one's misfortune or displeasure, except there is an unavoidable need for it, and to fail to acknowledge the pains this gives is to be aggressive or to disrupt social equilibrium and friendly relations. In terms of Schwartz's Value Constructs [15], reference to such experiences opens the speaker negatively to the construct of benevolence, and may depict one as being uncaring, as neglecting rapport, and therefore as being impolite ${ }^{2}$.

The signals Menkae Wo/Mo yaw/w'amanehunu (I don't mean to rake up your pains/suffering or I don't mean to

\footnotetext{
${ }^{2}$ See S. H. Schwartz, 1992: 44; Helen Spencer-Oatey, 2005: 105-107.
}

remind you of your pains/suffering) are usually employed in such pre-eventive apologies as in the following:

\section{A.W'anim se me obi a minim no. Mepa wo ky\&w, y\&ahyia da?}

(Your face resembles me someone who I know him. I doff

you cap, We have met before?)

('You look familiar. Please, have we met before?')

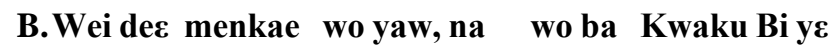 m'adamfo.}

(This as for I not remind you pain; before, your son $\mathrm{Kwaku} \mathrm{Bi}$ is my friend.)

('I don't intend to remind you of your pains. Your son Kwaku Bi was my friend.')

In B's speech, it becomes evident that the addressee's son is dead. Certainly being reminded of the loss of one's son can be painful, and the apology Wei dee menkae wo yaw ((I don't intend to remind you of your pains) is to address this face threat. Agyekum (2004: ibid) pertinently reports of the use of pre-eventive apologies in remniscential oaths.

\section{OVERClaIm to SOCIAL ATtRIBUTES/RESPECTABILITY}

The Akan society is organised upon an overriding idea of equality and oneness. This philosophy is so strong that undignified attributes which are conspicuous or known by all are still normally not referred to. A case in point is the royal maxim 'Yenkyere akoa ase'. (It is forbidden to show that one is a slave or the offspring of a slave'. Among the aspects of solidarity in the Akan society is that in formal or polite interaction, the speaker would, reflecting Leech's 'minimise dispraise to other' and 'maximise praise to other'. From this standpoint, any act which tends to indicate praise to the speaker or which even tends to put him/her at par with the addressees is considered as constituting an overclaim to social attributes or respectability. Associated with this idea of overclaim is the idea of social or universal principles which are the inputs individuals use to process information about their value or face. According to Spencer-Oatey (2005: ibid) in her comment on Simon [16]:

...people's claim to identity is based on the positive social values that they associate with their various self aspects. Some of their self-aspects are more important to their identity than others, and so sensitivity develops around these self aspects. Then if these self-aspect sensitivities are challenged or undermined, people may receive a threat to their face...

Schwartz and Owens [17] provide a compilation of these self-values.

Since face needs (and therefore Self-Values) of interactants are held to be in constant interaction (or conflict) with one another, any attempt to enhance one's self-value or that of another is seen as laying a stronger claim to that value, or causing a disequilibrium to the onset face distribution, and thereby reducing or challenging the access of the addressee to the value. It is in this sense that an attempt by 
Akan to directly or otherwise accord him/herself a self-value can be seen as constituting a face threat. In the following speech, a woman who is accused of neglecting a child in her care argues that being a mother herself she knows the needs of children and would not be the one to neglect a child:

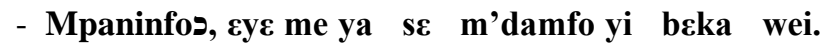
Megyina ha yi, menso mawo a mekuta mmamu mmiensa.

- (Elders, it gives me pain that this my friend will say this. Standing here, I also have born and I hold three full children.)

- ('Elders, I'm saddened that my friend is impugning this to me. As I stand here', 'I'm also a mother, with three solid children')

Her speech was met with stiff reaction from the elders: ' $\mathrm{Na}$ hwan na ye bonin w $\mathrm{ha?'} \mathrm{(But} \mathrm{who} \mathrm{among} \mathrm{us} \mathrm{here} \mathrm{is} \mathrm{sterile?)}$ 'Obiara nso nye abofra $\mathrm{w}$ ha'. (None here is a child) 'Kasa yiye' (Speak politely.). By claiming for herself the self-aspect of biological productivity, the woman is deemed to be offending all childless people in the gathering and perhaps those who are connected to those gathered. This could be averted if the pre-act signal scbe had preceded her description of herself:

\section{(Megyina ha yi, sebe, mmamu mmiensa.) \\ - (I stand here this, apologies, I also have born and I hold children-full three.) \\ - ('As I stand here, apologies, I have also given birth, and I have three solid children.)}

And this would have neutralised the face-threat associated with her self-value. Yankah has this to say about the use of such apologetic strategies in neutralising face-threatening potency:

The phrase [scbe] and its related forms disclaim any possible impression of irreverent or offensive intent in the use of language. Alternatively, an apology may aim at narrowing the referential focus of a remark or an apparently offensive language, and properly define the ratified addressee. 'My words are not directed at the entire august congregation', the speaker may imply 'They have a narrower target [18].

As intimated above, associated with the FTA nature of self-value is the underlying factor of conflict. A positive self-value is seen to stand in juxtaposition automatically with its negative equivalent. Put differently, a positive self-value works as a kind of trajectory which calls up its opposite, and vice versa. This is because, effectively, the positive and the negative are held to be conflicting values and properties in the same lexical field. Spanning the two ends of the same line of thought, they are held to have a magnetic attachment to one another. It is in this sense that, for instance, reference to one's procreative abilities is seen to evoke automatically the childlessness or sterility others. Similarly, the mention of one's achievements will be seen as an indirect reference to someone's failure. There is therefore the need for apologetic signals to disclaim such latent or unintended face-threats in order that the rapport may be maintained.

\section{Proverbs AS Overclaims}

The proverb lays a strong claim to line of thought, and employing the traditional wisdom encapsulated in the proverb in one's speech gives the claims some anchorage which gives it the quality of incontestability. Generally, knowledge of this cherished lore is seen as an index to communicative competence as well as to wisdom and good judgement. The use of proverbs when talking to older people or chiefs is therefore considered an overclaim to wisdom, and this is deemed to threaten their face. In formal situations, proverbs are used in with high exigency because of the sociopragmatic principle which Yankah explains:

While elders do not generally feel restrained in their application of the proverb when speaking to younger listeners or co-equals, a non-adult may not only qualify a proverb used; he may omit it altogether when speaking to an adult [19].

Yankah clarifies further that a colleague strategically omitted a proverb he had used in much the same circumstances when he was talking to the King of Asante because 'he did not want to sound overly didactic in the presence of such a superior as the great king of the Asante traditional state.' (Yankah, ibid) Where one has to use proverbs before one's superiors, one is required to employ a profuse use of politeness strategies including apologetic signals (usually scbe) honorific titles and names for the addressee, and deference strategies which distance one from the source of the wisdom of the proverb. To do this, one credits the proverb to elders (Mpaninfoכ), and one sometimes includes the elders in the context of speech in the reference of 'mpaninfoכ'.

\section{COMMANDS OR REQUESTS}

That imperatives are face-threatening or have impoliteness implications underlies Lakoff's politeness maxims: 'Give options' and 'Don't impose'. Similarly, Brown and Levinson [ibid] see imperatives in terms of negative politeness, and suggest the use of on-record and off-record negative as well as positive politeness strategies to address the face wants. The adoption of such pre-eventive apology strategies is aimed at softening the encroachment on the addressee's freedom of action and freedom of imposition.

In our discussion of requests and pre-eventive apologies, we would agree with Obeng [20] that Akan requests are not inherently face threatening since they are not considered as impositions. As observed in Sekyi-Baidoo [21], Akans (and people of other cultures) distinguish between face-threatening and non-face-threatening requests, further between mild and grave or severe face threatening requests. It is observed in this paper that some requests are considered essentially as a show of solidarity, trust, esteem and politeness, and such requests are not face-threatening. For the others, a request may be considered as a mild or a severe face threat depending on how it conforms to or violates 
established relationships or ethnography as evident in the variables of gender, rank, age, power and distance. For instance, vis-à-vis the politeness variables of rank, power and distance, to ask the chief in public to consider another option other than what he has chosen is seen as a potentially grave violation, and it is for such grave violations that pre-eventive apologies are used. Thus, the above suggestion would have been captured as:

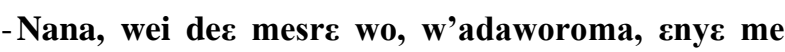

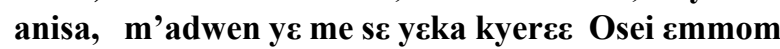

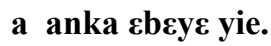

- (Nana, this rather I beg you, your mercy, it not is me disrespect, my mind is that we tell to Osei instead (if) rather it will be well.)

- ('Nana, this is just to beseech you, by your grace, I don't mean to be disrespectful' I think it would be effective if we told Osei rather.')

Apologetic forms in such grave violations involve a strategic non-acknowledgement of the violation, as though to say that the violation is itself unspeakable, and as though the acknowledgement is itself face-threatening and impolite. And indeed, it will be a grave impoliteness for one to acknowledge, for instance, that a citizen is sending the chief in a context which cannot be considered to be very informal. In this pre-eventive apology strategy then, there is an attempt to redefine the illocution from a grave violation to a non-FTA illocution or to a non-grievous FTA.. This is captured in such redefining phrases as 'Mensommaa Wo', (This is not to mean I have sent you) and cnye me anisa (This is not to mean I am disrespecting you). The use of the negation elements is characteristic of such redefinition of illocution.

\section{INTERRUPTIONS IN SPEECH/DIGRESSIONS}

Interruptions and digressions voilate the maxims of manner and relevance in Gricean cooperative principles. They are also seen in Brown and Levinson (1987: ibid) and Terkorafi [22] to have implications for politeness. Of the two, interruptions (relating to maxim of manner) are considered more face-threatening than digressions (relating to relevance). This is because whereas digressions are considered speaker-oriented or self-pointing FTAs, interruptions are considered addressee-oriented. In high formality contexts where one is expected to stay within the topic or the end of discourse, digressions are deemed to be highly face threatening. Digressions are signalled with the following:

Wei dę mede retwa mu ara.

- (This rather I just use in cutting.)

- (I am just interrupting with this.)

\section{Mesre mo, momma menfa wei ntwa mu.}

- (I beg you, you-PL let me take this cut in.)

- (I beseech you, permit me to cut in with this.)

In pre-eventive apologies relating digression, the speaker acknowledges or signals such digressions. In the first sentence above, this is done with the expression 'wei de $\varepsilon$ ' (as for this) which points to the idea of contrast. 'wei' (this) presupposes that or those i.e. the digression against the other aspects of the discourse. In the second sentence, the same textual demonstrative wei' (this) is employed. Added to this is the expression 'twa mu' (cut in) which also presupposes divergence from an existing line of discourse. 'Twa mu' (cut in) also presupposes brevity, and can be as conforming to Brown and Levinson's negative politeness strategy of minimizing imposition. Thus, in the pre-eventive apology is an acknowledgement of digression or divergence and a promise of brevity which signals reduced face threat. In the first expression, the politeness is enhanced by the further reinforcement of the promise of brevity with the expression 'ara' (approximately just). In addition to its suggestion of brevity and the further minimization of imposition, ara also plays down the importance of the digression itself, and reduces the possible effect it may have on the running discourse. In the second, the use of the request form, momma (permit) can be seen as an acknowledgement of possible imposition, and an attempt to avoid such an imposition by deferring the permission for the digression to the addressee. In addition to the use of the above strategies acknowledgement of possible imposition, minimization of imposition, promise of brevity, use of request form or deference to addressee -honorific forms as 'Mpaninfo' (Elders), Nananom (Grandsires) etc. may be used to support pre-eventive apologies in order to enhance the weight of politeness.

Interruptions are apologetically signalled with the expression:

\section{Mentwa w'ano \\ - (I not cut your month.) \\ - ('I don't mean to/this is not to interrupt you.')}

The strategy in this pre-eventive apology is the avoidance of acceptance of imposition, that one is actually interrupting an addressee. This can be seen as Off-Record Negative Politeness strategy. To this may be added honorific address forms - 'Opanin' (Elders), 'Nana' (Grandsire, Chief, Royal One), 'Me nua' (My brother/sister - which is an inclusive or in-group marker).

\section{Pre-EVEntive APOLOGIES, FACE AND (IM)POLITENESS}

The function of apologies (pre-or post-eventive) is considered generally as a way to 'redress face-threatening behaviour or to repair social relations' [23]. This repair function of apologies is acknowledged by Holmes (ibid) and Agyekum (ibid). Studying parliamentary discourse, Christie (ibid) observes, however, that apologies may perform speaker-oriented or self-enhancing functions:

... apologies for putative offences against the transactional norms relating to quality can be seen as a means by which MPs enhance their own standing in relation to their interlocutors.

Similarly, whereas pre-eventive apologies are basically potentially polite or politic behaviour, they may be organised in a way as to show impoliteness. In this sense, the very face-saving act becomes the basis for face-threat. This situation reiterates Holmes, Fraser and Nolan [24] and Watts 
[25], that politeness or impoliteness is purely contextual rather than linguistic, and are therefore not inherent in the use of any linguistic structures.

At this juncture, it may be useful to distinguish between notional and pragmatic politeness of linguistic expressions [26]. Notional politeness refers to the natural semantic or cognitive property of certain expressions to be used for face-threats or as positive politeness expressions. This kind of politeness is what generally was advanced by Brown and Levinson in which they attribute politeness to certain expressions. Such a stance has been widely criticized by authors such as Fraser and Nolan, Holmes, and Watts for whom politeness emerges in the realities of human interaction. By the distinction between notional and pragmatic politeness, we refer to the relationship between the general, the commonplace meaning or the semantic politeness resource of a linguistic expression, on the one hand, and the pragmatic politeness meanings it achieves in the actual context of speech on the other, and attention is paid to the cognitive as well as pragmatic principles which do negotiate the relationship (especially, the contrast in categorization and depth of politeness or impoliteness) between the cognitive sense of an expression and the pragmatic politeness effect it has in the actual context of its use.

Such a dynamism may be useful to politeness analysis in distinguishing what may be called direct or indirect (im)politeness. But more importantly, such dynamism has implications for such evaluations of a speaker as being witty, sarcastic, bold, careless etc. In the impolite uses of pre-eventive apologies, there is the movement from notional politeness to pragmatic impoliteness. Here, the addressee employs apologetic signals which are seen to have cognitive or semantic politeness properties, but uses them in a way as to threaten the face of the addressee. In such instances, the impoliteness may be pragmatic, but not cognitive. The impoliteness comes in the flouting of felicity conditions $\mathbf{1}$ and 2, when an a non-FTA expression is preceded with a pre-eventive apology as though it is face threatening, or when an expression is preceded with an incommensurate apologetic form The IFID forms for pre-eventive apologies, especially $s \varepsilon b e$, is often employed in informal contexts to draw attention (sometimes humorously) to a face-threatening interpretation of an idea which is in itself not face-threatening.

Sexual images are the most common images called up by such subversion. The expression which becomes the trajectory for such sexual images is usually one that shares some homonymic or polysemic relationship with any expression associated with sex or which captures any of the activities associated with sex. Commonest of such trajectory expressions include 'di' (eat) which is homonymous with 'di' (to have sex with). Others include insertion expressions such as wura mu (enter) hye mu (enter/stay inside), 'pia so' (push in); withdrawal expressions such as $t u$ (firi) (pull out of); and such sexual organ images as 'tokuro' (hole), and 'abaa'/poma (stick/rod). Examples of such humorous examples include

Sebe, me wuraa (dan no) mu.
- (Apologies, I entered the room in.)

- ('Excuse me to say I entered the room'.)

'Sebe pia dua no so.'

(Apologies, push on the stick.)

Excuse me to say push in the stick.

Again, in situations of implicit or explicit dissimilarity or divergence, the apologetic formula is attached to an otherwise plain divergence as a way of invoking a comparison that may be unfavourable to the addressee or to a third person. By attaching the pre-eventive apologetic form, the speaker draws attention to the fact that the divergence is not balanced but tilted in favour of one and against the other. For instance, the following divergences are normally balanced:

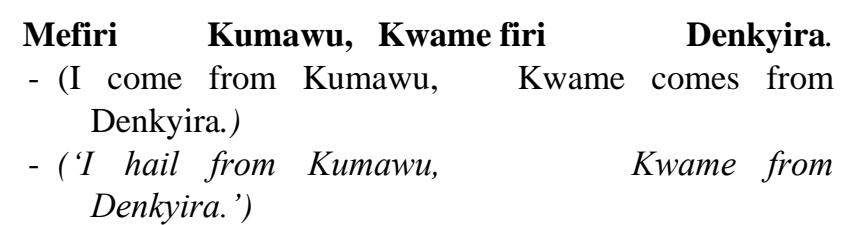

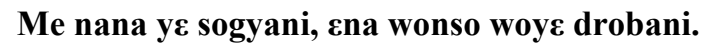

- (My grandsire is soldier, and you also are driver.)

- ('My grandsire is a soldier, and you are a driver.')

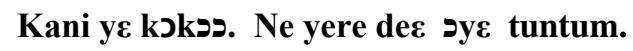

- (Kani is fair. His wife however she is dark).

- ('Kani is fair. His wife is however dark.')

\section{'Mew mma-mu miensa. Me nua yi so wə mmiensa saa'. \\ - (I have children full three. My brother this too has three also.) \\ - ('I have three children. This brother of mine also has three.)'}

However the addition of the apologetic term sebe as in
Mefiri Kumawu, Kwame firi
s\&be Denkyira.
(I come from Kumawu, Kwame from apologies Denkyira.)
I hail from Kumawu, and Kwame from, apologies, Denkyira.

'Me nana ye sebe sogyani, ena wonso woye drobani'. (My grandsire is, apologies, soldier, and you also are driver.) (My grandsire is, apologies, a soldier, and you are a driver.)

hieightens the value of the attribute associated directly or reflectively with the speaker and downgrades the other, thereby threatening the face of the person with whom this downgraded attribute is associated. In

\section{Mefiri Kumawu, Kwame firi scbe Denkyira.}

(I hail from Kumawu, and Kwame from apologies Denkyira.)

Kumawu is, by the use of ssbe, presented as a more reputable place than Denkyira, or that Denkyira is disreputable. Similarly, the dark complexion is denigrated in favour of fair complexion in

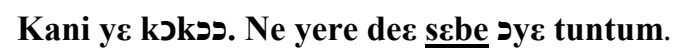


(Kani is fair. His wife is apologies however dark.)

\section{In}

Mewə mmamu miensa. Me nua yi so wə sebe mmiensa saa.

(I have three children. This brother of mine also has apologies three.)

The use of the apologetic signal seems to point to one of the following interpretations:

1) Normally speaking, my brother shouldn't have as many children as I have.

2) There is something fishy about my brother having three children: there are bizarre circumstances surrounding the birth of perhaps one of them.

3) My brother should have more than three children, but for some strange or painful events.

In (2) and (3), the face threat is in the fact that the painful experience surrounding the three children attributed to the brother is evoked by the use of sebe thereby challenging the joy or satisfaction which the brother, unlike the speaker, would attach to the three children.

Additionally, in contravention of the third felicity condition:

The IFID which is the formulaic expression must be commensurate with the level of face threat

the face-threat associated with an expression or the state, being or thing it represents may be intentionally downplayed by the selection of a less commensurable apologetic form, or heightened to look more face-threatening by the use of over-elaborate or more powerful apologetic signals. Politeness strategies are generally commensurate with the level of potential or real face threat; and therefore by choosing a less commensurable apologetic strategy, the speaker implies that (s)he does not recognize the actual level of face threat. By selecting more powerful apologetic strategies on the other hand, a speaker may be seen as heightening the face-threat to a level as suggested by the potency of the apologetic formula, and thereby threatening the face of the one with whom that attribute is associated. To illustrate, the multiple use of sebe as in sebe, scbe, sqbe, sebe, sebe, or sebe mpre aduasa (apologies thirty fold):

Nana, moanim o, mehunuu se sebe, ssbe, ssbe, sebe, sebe mene me yere dii mpaso agorə a edi kan no ses na w'afa afuru dada.

(Nana, this is unfortunately said in your presence; I discovered later that apologies, apologies, apologies, apologies, apologies, when I, engaged in the first bed-game with my wife, she was already pregnant.)

May be interpreted as showing the speaker's regret or revulsion for having any such affair with the woman. This profusion of apology has an affective meaning of showing despication for the woman, or rather for the fact that he, the addressee, had an affair with her. Thus, by apologizing so profusely for an action that does not directly offend the addresses, the speaker is drawing attention to another dimension of the act, which one may interpret as his regret.
Similarly, in

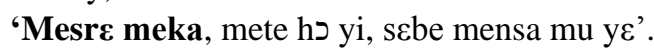

I beg to say that in my life I am quite wealthy.

The use of 'mesre meka' (I beg to say) instead of 'scbe' as an apologetic attachment to the mention of one's positive attributes may be seen as an attempt to draw attention to or mock addressees who may not have such attributes - wealth, in this case.

Impoliteness may involve the use of insults and the references to the addressee's negative attributes directly threaten the face of the addressee (addresse-oreinted), or raw references to scatological material and references to the speaker's own positive attributes directly show the speaker's own lack of knowledge of the society's politeness (speaker oriented). Addressee-oriented impoliteness generally requires stronger or more emphatic apologetic signals than the speaker-oriented ones. Thus, when a speaker chooses strong and emphatic apologetic signals for what is generally regarded as an speaker-oriented impoliteness, he/she succeeds in drawing attention to the fact that what he/she is referring to is intended to be a threat to the face of the addressee. It is in this sense that the reference to one's wealth as in

\section{Mesre meka, mete hə yi, me nsa mu ye.}

('I beg to say, even as I live, I am wealthy.')

May be seen as an indirect face threat. This is because mesre meka (I beg to say), Mpaninfo, Mo anim a (Elders, this is unfortunately said in your presence) or enye me anisa (I don't mean to be impolite) is considered as an emphatic apologetic signal, and should not be normally attached to a speaker -oriented impolite form such as mensa ти ує (I am endowed/I am wealthy). The face-threat associated with any of the following

\section{'Mesre meka, mete hə yi, mensa mu ye.' \\ (I beg to say, in my life I am well endowed)}

\section{'Sebe mpre aduasa, mawo mmiensa'.}

(Apologies a thirty times, I have three children.)

depends on the apparent mismatch between the apologetic forms and the face-threatening statements to which they are attached.

The pragmatic politeness of an apologetic form is influenced by the non-verbal features that accompany it. This may include the rapidity or speed with which the apologetic form is said, the force or emphasis and the volume. It is generally expected that normal speed, emphasis, volume as well as facial expressions will be attached to the apologetic form as well as the FTA to which the apology is attached. Any attempt to stray from the normal may be seen possibly as an attempt to heighten the apology if one is most fortunate, or normally as an attempt to challenge, neutralize or contradict the notional politeness conveyed through the .signals.

\section{CONCLUSION}

In this paper, we have distinguished Akan pre-eventive 
apologies from the post-eventive ones which have been the focus of most of previous research. Again, pre-eventive apologetic forms have been distinguished from similar aspects of politeness, especially those that are often used in normal requests. We have looked at the three felicity conditions of the existence of face threat, the existence of need and inevitability, and the use of appropriate linguistic signals; and in furtherance of the condition of the existence of face threat, various domains of face threat have been discussed with their respective issues of need and appropriate signals. The paper has also discussed situations in which a pre-eventive speech act may misfire or be exploited for impoliteness effects. Again, a distinction is made between notional and pragmatic politeness, in order to account for the relationship between the politeness which naturally embodied in the apologetic signals employed, and the actual politeness achieved through the exploitation of the felicity conditions guarding pre-eventive apologies.

\section{REFERENCES}

[1] P. Brown and S. C. Levinson, Politeness: Some Universals in Language Usage, Cambridge: Cambridge University Press, 1987.

[2] G. N. Leech, Principles of Pragmatics, London: Longman, 1983.

[3] S. Ide, "Formal forms and discernment: Two neglected aspects of universals of linguistic politeness," Multilingua, vol. 8, 1989, pp. 223-248.

[4] Y. Matsumoto, "Reexamination of the universality of face: Politeness phenomena in Japanese," Journal of Pragmatics, 1988, pp. 403-426.

[5] H. S. Oatey, "(Im)politeness, face and perceptions of rapport: Unpackaging their bases and Interrelationships," Journal of Politeness Research, 2005.

[6] J. Holmes, Women, Men and Politeness, London: Longman, 1995.

[7] E. Goffman, Interaction Ritual: Essays on Face-to-Face Behavior, New York: Doubleday Anchor, 1967.

[8] M. Terkourafi, "Beyond the micro-level in politeness research," Journal of Politeness Research, 2005, pp. 237-262.

[9] K. Agyekum, "Apology: A repair mechanism in Akan social interaction," South African Journal of African Languages, Linguistics, vol. 26, no. 2, 2006, pp. 53-57.

[10] W. Ronald, How Conversations Work, Oxford. Basil Blackwell, 1985.

[11] S. Blum-Kulka and E. Olshtain, 'Requests and apologies: A cross cultural study of speech act realization patterns," CCSARP Applied Linguisitcs, vol. 5, no. 3, 1984, pp. 196-213.

[12] M. L. Wagner, Apologies, UCOA Handbook, 2000.

[13] S. Ron and S. W. Scollon, Intercultural Communication. Oxford: Blackwell, 1995.

[14] A. Kofi, "The pragmatics of requests in Akan communication," Legon Journal of the Humanities, 2005

[15] S. H. Schwartz, "Universals in the content and structure of values: Theoretical advances and empirical tests in 20 countries," Advances in Experimental Social Psychology, San Diego: Academic Press, 1992, pp. 1-65.

[16] B. Simon, Identity in Modern Society, A Social Psychological Perspective, Oxford: Blackwell, 2004.

[17] V. Owens, "Extending the cross-cultural validity of the theory of basic human values with a different method of measurement," Journal of Cross-Cultural Psychology, vol. 32, no. 5, 2001, pp. 519-542

[18] K. Yankah, Speaking for the Chief: Okyeame and the Politics of Akan Royal Oratory, Bloomington and Indianapolis: Indiana University Press, 1995, p. 56.

[19] K. Yankah, The Proverb in the Context of Akan Rhetoric, New York: Peter Laing, 1989, p. 107.

[20] S. Obeng-Gyasi, "Requests in Akan discourse," Anthropological Linguistics, vol. 41, no. 2, pp. 230-251, 1999.

[21] Y. Sekyi-Baidoo, 'Requests and politeness," University of Education, Winneba, 2008

[22] M. Terkorafi, "Generalized and particularized implicatures of politeness," Perspectives on Dialogue in the New Millennium, Amsterdam: John Benjamins, 2003, pp.151-166.

[23] C. Christie, "Politeness and the linguistic construction of gender in parliament: An analysis of transgression and apology behaviour," Sheffield Hallam Working Papers: Linguistic Politeness on Politeness - Working Papers on the Web, 2005, p. 25

[24] B. Fraser and W. Nolan, 'The association of deference with linguistic form," International Journal of the Sociology of Language, 1981, pp. 93-111.

[25] R. J. Watts, Politeness, Cambridge: CUP, 2003.

[26] Y. Sekyi-Baidoo, 'Politeness between language and context: Notional and pragmatic politeness," Public Lecture, Faculty of Languages Education, University of Education, Winneba, June 2008.

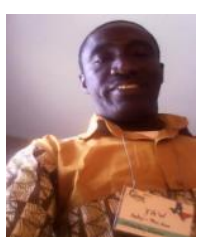

Yaw Sekyi-Baidoo was born in Akan parents in Ghana in July 1965 . He was educated at the University of Cape Coast, Cape Coast (Ghana) where he obtained his B.A. the (Hons.) English, diploma in education (1989) and M.Phil English (2002); and at the University of Ghana, Legon, where he obtained the M.Phil in African Studies (literature) in 1994

He has been on the academic staff of the University of Education since 1996, and has served as a head of department of English and a head of the then Department of Ghanaian Languages, which is currently the Faculty of Ghanaian Languages. He has also been the dean of the Faculty of Languages, and has served on top university committees and boards including the Governing Council. He is currently director of the Division of International Relations and Public Affairs of the University of Education, Winneba. He has published textbooks for tertiary studies in English and Linguistics as well as several articles and chapters in both language and literature. He currently concentrates on onomastics and humour besides topics relating to pragmatics.

Prof. Sekyi-Baidoo is a member of the American Names Society, Linguistics Society of America, and Association of African Studies in Africa, Linguistic Politeness Research Group, Linguistics Association of Ghana, American Names Institute and others. 